\title{
Kvalitetssikring, eksplicitisme og undervisererfaring
}

\author{
Anne-Marie S. Christensen, adjunkt, ph.d. Institut for filosofi, paedagogik og religionsstudier, \\ Syddansk Universitet
}

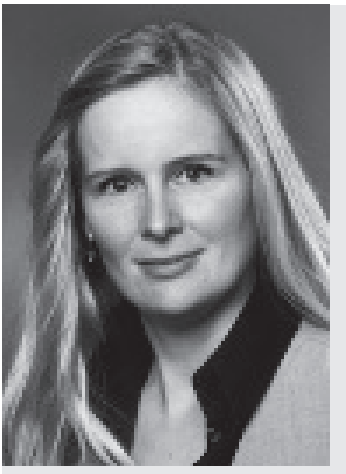

Anne-Marie S. Christensen er ansat som adjunkt ved Institut for filosofi, pædagogik og religionsstudier på Syddansk Universitet. Hun har en ph.d. i etik og arbejder på et forskningsprojekt om etisk erfaring, der bl.a. har resulteret i en bog om moderne dydsetik. Hun underviser på bachelor-, kandidat- og ph.d. niveau, og har været med til at udarbejde kompetencemål for uddannelsen i filosofi på SDU

\section{Reviewet artikel}

Der er $i$ disse år et stigende onske om at kvalitetssikre universitetsundervisning. På trods af mange gode intentioner kan denne udvikling give problemer på to fronter. For det forste er der en potentiel spanding mellem undervisningens erfaringsbaserede karakter og de eksterne og kvantitative kriterier, der ofte opstilles $i$ kvalitetssikringen, dens eksplicitisme. For det andet skelner man $i$ kvalitetssikringen sjoldent mellem, om man onsker at overvage eller at udvikle undervisning, selvom disse to målsxtninger grundlaggende er forskellige.

\section{Indledning}

Der er i disse år et stigende fokus på at kvalitetssikre universitetsundervisning. ${ }^{1}$ Selvom ingen kan være uenig i, at man bør stræbe efter den størst mulige kvalitet $\mathrm{i}$ undervisningen, er der alligevel gode grunde til at undersøge, om de redskaber, som bruges i kvalitetssikring, faktisk fremmer den gode undervisningspraksis. Denne artikel vil bidrage til en sådan undersøgelse. Først præsenteres en kritisk beskrivelse af en række almindeligt anvendte redskaber i kvalitetssikring af universitetsundervisning under overskriften eksplicitisme. Dernæst bruges wittgensteinianske og neo-aristoteliske indsigter til at udvikle en filosofisk beskrivelse af undervisningens erfaringsdimension. Slutteligt vises det, at der findes en potentielt problematisk spænding $i$ forholdet mellem eksternt fastlagte og eksplicitte kvalitetsmål og det ansvar, der udspringer fra underviseres egen erfaring. Dermed kan man sætte spørgsmålstegn ved, om alle forsøg på institutionelt at kvalitetssikre universitetsundervisning faktisk støtter kvaliteten af samme undervisning.

\section{Kvalitetssikring og eksplicitisme}

En række af de initiativer, man i disse år introducerer for at sikre kvaliteten af universitetsuddannelser og den undervisning, som indgår i dem, deler to grundlæggende fællestræk. Det første fællestræk er, at disse initiativer ofte tager en bestemt form, som man kan beskrive med betegnelsen eksplicitisme. Det andet er, at de ofte præsenteres med et todelt formål. Begrebet kvalitetssikring omfatter i denne sammenhæng alle initiativer, der indføres for at sikre kvaliteten af undervisningen på universiteter og længerevarende uddannelser generelt. Fra ministerielt hold har man i de seneste år specielt fokuseret på studenterevalueringer og de kriterier, som indgår i akkrediteringsprocessen. ${ }^{2}$ Blandt disse finder man oplysninger om ledighedsfrekvenser, frafald, læringsudbytte og igen studenterevalueringer (se under målepunkter i Ace Denmark 2009). Et bemærkelsesværdigt træk ved mange af disse initiativer er, at de deler den samme, grundlæggende form, som man kan betegne som eksplicitisme. Eksplicitismen betegner ideen om, at kvalitetskriterier for god undervisning principielt altid kan gøres gennemskuelige, ikke bare for specialister, men også for eksterne aktører. Eksterne aktører skal her forstås som alle, der har interesser $\mathrm{i}$ forhold til universitetsundervisning, men som ikke selv underviser på en bestemt uddannelse, for eksempel studerende, ledere, repræsentanter fra evalueringsinstitutioner, politikere og den almene befolkning. Rationalet bag eksplicitismen ligner der- 
med rationalet bag tidens generelle bevægelse hen mod et "audit society«, dvs. et samfund, hvor alt principielt kan underkastes revision (se for eksempel Power, 1997 og O’Neill, 2002). Eksplicitismen repræsenterer således den antagelse, at man vha. kvalitetssikringen kan eksplicitere de implicitte kriterier eller standarder for god undervisning, der ligger bag det øgede (politiske) fokus på akkreditering, gennemførelsesstatistikker, dimmitendledighed, standardiserede evalueringer med statistisk læselige svarmuligheder osv.

De initiativer, som indføres for at sikre kvalitet $i$ universitetsundervisning, ligner imidlertid ikke bare hinanden ved deres form, eksplicitismen, men også ved, at de ofte præsenteres med en todelt målsætning. Den første er, at de skal gøre undervisningen tilgængelig for en ekstern evaluering. Argumentet er, at en uvildig kvalitetssikring kræver, at eksterne aktører er i stand til at evaluere undervisningen. Kvalitetssikring bruges dermed som grundlag for et krav om sammenlignelige resultater fra forskellige undervisningssituationer og forskellige uddannelsessteder; et krav som igen medfører et øget fokus på målelige kvalitetsstandarder. Ønsket om en ekstern evaluering følges dog ofte også af en anden målsætning, nemlig at de redskaber, som stilles til rådighed $\mathrm{i}$ forbindelse med kvalitetssikringen, skal bruges af den enkelte underviser, eller det fællesskab hun er del af, til at reflektere over, understøtte og, hvis det er nødvendigt, forbedre egen praksis. Kvalitetssikring ses her som et positivt og fremadrettet instrument til forbedring af undervisningen, der samtidig fremmer lærerens ansvarlighed over for egen undervisning. Dvs. at kvalitetssikring også ofte præsenteres som et redskab til intern evaluering.

Antagelsen om, at kvaliteten af undervisning kan sikres alene ud fra de instrumenter, som falder inden for eksplicitismen, er dog forbundet med en række mulige problemer. For det første kan dens fokus på målelige resultater betyde, at kvalitative dimensioner $\mathrm{i}$ undervisningspraksissen skal bedømmes vha. en kvantitativ målestok, dvs. at man i målingen af kvalitet forandrer det fænomen, man måler på. ${ }^{3}$ For det andet kan eksplicitte kvalitetskriterier skabe nye incitamenter, som ikke udspringer fra undervisningen eller uddannelserne, og som ikke nødvendigvis fremmer deres kvalitet. Det store fokus på studenterevalueringer kan for eksempel stimulere undervisere til at prioritere det underholdende frem for det svære stof $i$ deres undervisning eller til at tilrettelægge undervisningen til at imødekomme de studerendes forventninger frem for deres undervisningsbehov. Man løber den samme risiko for at skabe nye, undervisningseksterne incitamenter i forbindelse med alle politiske og administrative kriterier, der bruges til at bedømme uddannelser, som for eksempel beslutningen om at lade uddannelsernes indtægt afhænge af STÅ-midler. Og, som filosoffen Onora O'Neill bemærker det i sin undersøgelse af "the new accountability« i Storbritannien, så er »Perverse incentives" også »real incentives", (O’Neill, 2002, s. 55). O'Neill uddyber således: "The new accountability is widely experienced not just as changing but (I think) distorting the proper aims of professional practice and indeed as damaging professional pride and integrity" (ibid., 50). Opstillingen af nye incitamenter medfører således en reel risiko for, at man undergraver den praksis, den skulle sikre. Kvalitetssikring, der tager form som eksplicitisme, kommer nemt til at skabe sådanne nye incitamenter, og disse er specielt problematiske, fordi de netop fremhæves som vigtige parametre for succesfuld undervisning.

Til de to første problemstillinger kan vi knytte en tredje, som skal undersøges i det følgende, nemlig at der er en potentiel modsætning mellem eksplicitismen og undervisningens erfaringsbaserede karakter. Eksplicitismen præsenteres ofte som et redskab, den individuelle underviser kan bruge til at blive mere reflekteret og bevidst om de overordnede målsætninger, der leder hendes praksis. Dette kan imidlertid kun ske, for så vidt som underviseren retter en del af sin opmærksomhed mod og organiserer sin undervisning efter de ekspliciterede kvalitetsmål. Men dermed opstår en fare for, at underviseren fjerner sin opmærksomhed fra de enestående og partikulære omstændigheder, som fremtræder i hendes konkrete erfaring med og aktuelle forståelse af sin undervisning. Dvs. at kvalitetssikringen kan flytte underviserens fokus væk fra den konkrete undervisningssituation.

\section{Undervisning som erfaringsbaseret praksis}

Modsætning mellem eksplicitisme og undervisning bliver specielt presserende, hvis man antager, at undervisning involverer en essentiel erfaringsdimension. Spørgsmålet er altså, om der er nogen grunde til at kalde undervisning erfaringsbaseret. Man kan fremhæve to begrundelser, der er hentet hhv. i common sense og en Wittgenstein-inspireret undersøgelse af regelstyrede praksisser.

Den første begrundelse udspringer fra et billede af betingelserne for vellykket undervisning, som forhåbentlig er fuldstændig ukontroversielt. En række af disse betingelser skal man finde blandt underviserens forudsætninger. En underviser skal have et overblik over det relevante faglige materiale, hun skal have en forståelse af, hvad undervisning er, og hun skal have forståelse for en række hensyn, der kan opfattes som eksterne i forhold til selve undervisningssituationen, men som er afgørende for, at den kan kaldes vellykket, for eksempel kursets placering i uddannelsen, de studerendes forkundskaber, hvilket materiale der eksamineres i, og hvad den studerende kan få brug for i udøvelsen af sit fag. Ligeledes vil det ofte være en styrke, hvis underviseren har en vis erfaring med undervisning. ${ }^{4}$ Det er således en betingelse for vellykket undervisning, at underviseren i planlægningen og udførelsen af under- 
visning trækker på sådanne forudsætninger. Men der synes stadig at mangle en nødvendig forudsætning for et vellykket undervisningsforløb, nemlig at underviseren er opmærksom på det, som sker $i$ lobet af undervisningen. Gennem ethvert undervisningsforløb får man en erfaring med og en viden om, hvilken undervisning der er bedst $\mathrm{i}$ forhold til dette hold, disse studerende, denne sammenhæng. Denne erfaring er nødvendig for kontinuerligt at kunne tilpasse og udvikle det konkrete undervisningsforløb, men den indeholder også en viden, som underviseren løbende kan akkumulere, således at vedkommende vha. sin erfaring simpelthen bliver bedre til at undervise med tiden. Man kan genfinde betydningen af den konkrete erfaring i det faktum, at man som uprøvet, grøn underviser ofte vil trække på erfaringer fra vellykkede undervisningsforløb, man selv har deltaget i, ligesom man vil hente hjælp hos mere erfarne kollegaer. Man leder så at sige efter rollemodeller, der kan udfylde det tomrum, som manglen på erfaring udgør (for betydningen af rollemodeller i etisk refleksion generelt se Hursthouse, 1999, s. 36-37, i situeret læring se Lave og Wanger, 1991).

Det er vigtigt at understrege, at undervisningens erfaringsbaserede karakter ikke betyder, at domme om, hvordan man bør undervise, er helt tilfældige. Når man trækker på sin erfaring i vurderingen af, hvordan man bedst opbygger sin undervisning, kan man selvfølgelig give, og afkræves, begrundelser. Man vælger at ændre fokus $i$ et kursus, fordi tidligere studerende har haft sværest netop ved det metodiske, ved litteraturen eller ved empirien. Man vælger at give mere plads til summegrupper og diskussion, fordi et bestemt hold har vist sig at få mest ud af at arbejde på denne måde, osv. Der er således intet, der tyder på, at domme baseret på erfaringsbaseret undervisning er irrationelle eller ubegrundede, spørgsmålet er snarere, hvordan vi skal give mening til ideen om en praksis, som både er rationel og essentielt erfaringsbundet.

Hvis vi fastholder, at undervisning, på trods af dens erfaringsbaserede karakter, er en rationel aktivitet, så antager vi også, at der findes kriterier eller regler, som vi bruger, når vi forsøger at give en vurdering af, hvad vi skal gøre $\mathrm{i}$ individuelle undervisningssituationer. Undervisning må altså $i$ en eller anden forstand være regelstyret, men spørgsmålet er, hvordan vi skal forstå de regler, vi følger, når vi underviser? En beskrivelse af sådanne erfaringsbundne regler finder man i en nutidig position inden for moralfilosofien, nemlig partikularismen. Den tager mange former, men det interessante $i$ denne sammenhæng er dens påvisning af, at domme om, hvad vi skal gøre, kan være afledt af to forskellige typer af regler eller standarder (den partikularistiske forståelse af regler udspringer fra Wittgenstein 1953, men nærværende fremstilling trækker primært på Garfield, 2000). Kontrasten mellem de to typer regler vises bedst vha. et eksempel, for eksempel to forskellige regelsæt, som man må kunne forstå og efterfølge, hvis man vil være en kompetent fodbolddommer. En dommer må for det første være i stand til at afgøre, hvornår der er scoret et mål i en fodboldkamp. Hun skal vide, hvad et mål er, hvordan det er tilladt at få bolden ind i målet osv. Men hun skal også kende de specifikke regler, der afgør, om der er scoret mål, nemlig at man kun kan score i modstanderens banehalvdel, og at bolden skal have passeret mållinjen mellem målstængerne og under overliggeren. Lad os kalde disse regler for målregler. Men hvis man har ambitioner om at blive fodbolddommer, skal man også - blandt andre regler - kende reglerne for frispark, for eksempel at der er frispark, når en spiller intentionelt går efter en modspiller i stedet for bolden, eller når hun bevidst obstruerer modspilleren. Lad os kalde dette frisparksregler.

Hvis man sammenligner de to typer af regler, er det klart, at der er en række ligheder imellem dem. For det første er målregler og frisparksregler handlingsledende, dvs. de foreskriver, at en dommer bør gøre noget bestemt, nemlig under de rette omstændigheder at dømme enten 'Mål' eller 'Frispark'. For det andet er begge grupper af regler konstituerende for fodbold, dvs. at hvis en dommer begynder at ændre på dem eller følge andre regler, vil hun ikke mere dømme fodbold. Og slutteligt er der intet mystisk ved hverken målregler eller frisparksregler, begge regelsæt kan læres af en almindelig person inden for en afgrænset tidsperiode, og der vil blandt eksperter være enighed om, hvad de foreskriver i konkrete situationer (den notoriske utilfredshed med fodbolddommeres kendelser har vist oftest andre årsager). En sammenligning viser dog lige så klart, at der er markante forskelle mellem de to grupper af regler, specielt synes der at være stor forskel på, hvad de kræver, at dommeren skal lære. En kompetent måldommer skal blot være i stand til at identificere boldens position $i$ forhold til målstregen, afgørelser der principielt kunne træffes af en maskine. Til forskel fra dette involverer domme om frispark mange forskellige elementer, for eksempel en forståelse af, hvilke handlinger der er tilladte i fodbold, hvilke handlinger spillerne faktisk udforer, hvad deres intentioner er osv. Den forste markante forskel mellem målregler og frisparksregler er altså, at hvor der er ét bestemt kendetegn ved mål, så er dette ikke tilfældet ved frispark. Den anden forskel er, at målregler sagtens kan læres uafhængigt af, om man har praktisk erfaring med fodbold; det kan frisparksregler ikke. Man kan sagtens lære en amerikaner, der aldrig har set en 'soccer-game', at bedømme, hvornår der er scoret et mål; for eksempel kan man tegne bane og mål op på et stykke papir. Men man kan ikke lære hende at dømme et frispark, hvis hun aldrig har set en tackling eller en nærkamp. Forståelsen af frisparksregler er således essentielt bundet til en erfaring med faktiske fodboldkampe.

Pointen er nu, at de regler, vi følger i undervisning, i langt højere grad ligner frisparksregler end målregler. Det betyder, at en fuld forståelse af, hvad der kræ- 
ves $\mathrm{i}$ en specifik undervisningssituation, forudsætter, at man $i$ et eller andet omfang selv har erfaring med undervisning. Det betyder også, at den viden, som man udøver i undervisning, ikke restfrit kan forklares på en måde, som ikke trækker på denne erfaring. Jeg vil i det følgende skitsere hvilke konsekvenser, der følger af denne forståelse af undervisning som en regelstyret og essentielt erfaringsbaseret praksis.

\section{Undervisning og praktisk fornuft}

Hvis vi vil undersøge erfaringsbaserede praksisser, kan vi hente hjælp i neo-aristotelismen, hvor sådanne praksisser gerne beskrives med udgangspunkt i det aristoteliske begreb om phronesis, praktisk fornuft. Undervisningsfilosofiske diskussioner af, om undervisning overhovedet kan kaldes en praksis, tager ofte Alasdair MacIntyres praksisbegreb som omdrejningspunkt (se MacIntyre og Dunne, 2002, Dunne, 2003 og Carr, 2003). Her vil vi dog tage udgangspunkt i Aristoteles' praksisforståelse. Fordelen er, at phronesis ifølge Aristoteles' beskrivelse tager den samme form i alle praktiske områder og udpeger praktiske grunde, som principielt er sammenlignelige (Aristoteles 1953, bog VI, s. 209). Dvs. at Aristoteles ikke - som MacIntyre - mener, at praksisser er lukkede aktiviteter, som etablerer praktiske grunde, goder, der er essentielt knyttet til og kun kan identificeres inden for denne praksis. Dermed kan vi vha. phronesis-begrebet udfolde ideen om, at den praktiske tænkning, som man udvikler gennem erfaring med undervisning, relaterer til og har samme struktur som praktisk fornuft generelt. Dvs. at vi kan fastholde, at overvejelser, der vedrører undervisning, ikke i udgangspunktet er i konflikt med det, der $i$ andet afsnit blev omtalt som undervisningseksterne hensyn, ligesom en neo-aristotelisk praksis-forståelse ikke på forhånd diskvalificerer ethvert forsøg på udefrakommende kvalitetssikring.

En forståelse af begrebet om praktisk fornuft kan tage udgangspunkt i Aristoteles' pointe om, at evnen til at handle rigtigt i praktiske situationer ikke udelukkende består i en tilbøjelighed til at handle rigtigt eller en abstrakt viden om generelle principper, men involverer begge dele, idet phronesis er en evne til at reflektere korrekt over, hvad man bør gøre i en bestemt situation (ibid. bogVI, s. 222). For at dette er muligt, må praktisk fornuft omfatte to forskellige elementer. For det første må den trække på en generel viden om det gode for individer, og det vil i forhold til undervisning sige alt, hvad der har betydning for god læring. For det andet skal praktisk fornuft kunne udmønte sig $i$ en konkret viden om den rigtige handling, således at man ved, hvad man skal gøre i specifikke situationer. Det er det første element, den generelle viden, der gør en underviser i stand til at forstå den konkrete situation, fordi man skal bruge den til at genkende de elementer, der kan have betydning for, at undervisning lykkes.
Men kompetencen hos den, der besidder phronesis, rækker ud over besiddelsen af generel viden. Den ligger netop $\mathrm{i}$ "the mediation between general and particular, in the ability to bring both into illuminating connection with each other. This requires receptiveness in her reading of particular situations as much as flexibility in her mode of 'possessing' and 'applying' the general knowledge« (Dunne, 2005, s. 376). Anvendelsen af den generelle viden er kontekstbundet, og de erfaringer, en underviser får i konkrete undervisningskontekster, reflekterer tilbage på denne viden. Desuden understreges det inden for en aristotelisk tradition, at det altid er det andet element, den konkrete erfaring af undervisningssituationen, der er udslagsgivende for en dom om, hvordan man bør undervise. Beslutningen udspringer fra forståelsen af den konkrete situation, man befinder sig i, eller, som Aristoteles formulerer det, »the decision lies with our perception« (Aristoteles, 1953, bog II, s. 110, se også bog VI, s. 215).

Denne beskrivelse af praktisk fornuft som phronesis viser os flere ting. For det første bliver vi i stand til at se, at den generelle viden om, hvad der er involveret $i$ forståelsen af god undervisning, er meget omfattende. Den trækker ikke bare på vores forståelse af det konkrete emne, undervisning generelt og læring, men også på forståelsen af forholdet mellem underviser og studerende, betydningen af uddannelse, forholdet mellem mennesker, sociale faktorer osv. Denne viden er vidtrækkende, mangefacetteret og dynamisk, alt sammen faktorer som indikerer, at den principielt ikke kan ekspliciteres. At vi ikke sætter os ned og prøver at udtrykke og rangordne de overvejelser, som vi inddrager, når vi reflekterer over, hvordan vi bedst underviser, er ikke bare udtryk for, at vi ikke tager os tiden til det. Det er også en konsekvens af den enorme kompleksitet, disse overvejelser afspejler. Forsøget på at finde ud af, hvad man bør gøre, er dermed ikke kun et spørgsmål om at identificere ét generelt princip eller en eksplicit standard og applicere dem på den konkrete situation, for korrekte domme kræver, at man trækker på hele sin viden om undervisning. Ifølge opfattelsen af undervisning som udøvelse af praktisk fornuft kan man altså ikke udtrykke og ordne alle betingelserne for god undervisning i eksplicitte principper. Den forste vigtige indsigt, som vi făr fra undersøgelsen af praktisk fornuft, er altså, at den viden, som leder udøvelsen af praktisk fornuft $\mathrm{i}$ undervisningssituationer, er ukodificerbar (begrebet introduceres i McDowell, 1979 og videreudvikles bl.a. i Hursthouse, 1999 og Lovibond, 2001).

Vi har set, at praktisk fornuft er en evne til at knytte generel viden sammen med enkelthederne i en specifik handling. Men det betyder, at praktisk fornuft også involverer en åbenhed over for verden, en opmærksomhed eller følsomhed over for de grunde, som er praktisk relevante i en bestemt situation. Dvs. at praktisk fornuft involverer dannelsen af en bestemt type følsomhed, 
som giver underviseren en forståelse for den konkrete situation, og i sidste ende udmønter sig i en viden om, hvilken handling denne specifikke situation kræver. Man kan dermed opfatte den praktiske fornuft parallelt til andre former for erfaring af verden; dens mål er at blive i stand til at identificere de relevante træk ved en situation og de grunde for handling, som disse træk afstedkommer (se også McDowell, 1996). Man kan således beskrive phronesis som en fornuftsstyret form for erfaring. Phronesis er en persons evne til at opfatte den eller de gode handlemuligheder i specifikke situationer, en evne som essentielt set handler om at erkende den foreliggende situation korrekt og som udvikles gennem kritisk udøvelse af netop samme evne.

Denne forståelse af phronesis som erfaring bruges ofte til at belyse læring af erfaringsbaserede kompetencer inden for uddannelsesfilosofien (jf. fx Smeyers, 1992 og Dunne, 1999). Idet phronesis beskriver en form for tænkning, som både involverer generelle kriterier og essentielt erfaringsbundet viden, kan begrebet i en læringssammenhæng mediere mellem opfattelsen af tavse, erfaringsbundne færdigheder og almen, teoretisk viden (se Saugsted 2005). I nærværende undersøgelse kan phronesis-begrebet hjælpe os med at forstå samspillet mellem undervisningens erfaringsdimension og de eksplicitte kriterier, som tilbydes i megen kvalitetssikring. Her finder vi nemlig endnu en vigtig indsigt i beskrivelsen af undervisning som udøvelsen af praktisk fornuft, nemlig at en opmærksomhed over for erfaringen af den konkrete undervisningssituation både er nødvendig for at undervise godt og for at udvikle en forståelse af, hvad god undervisning er (for en uddybning se Christensen, 2009 og 2008, kapitel 4). Men denne pointe står i skarp modsætning til den centrale antagelse bag former for kvalitetssikring, der tager form som eksplicitisme, nemlig at kvalitet kan beskrives vha. alment tilgængelige, eksplicitte, generelle principper. Dermed skygger eksplicitismen for den kendsgerning, at forståelse af god undervisning udspringer fra udøvelsen af god undervisning, og forståelsen af, at undervisere primært bør fokusere på erfaringen fra den konkrete undervisningssituation. Hvis undervisere målrettet forsøger at forstå egen praksis vha. de kriterier, som opstilles i eksplicitismen, så er der en reel risiko for, at hun underminerer kvaliteten af sin undervisning, fordi hun ikke i tilstrækkelig grad vil være opmærksom på den viden, som tilbydes $\mathrm{i}$ en reflekterende erfaring fra undervisningssituationer.

\section{Enten monitorere eller udvikle kvalitet}

Gennem forståelsen af undervisningens erfaringsbaserede karakter får vi stillet skarpt på tre vigtige pointer vedrørende forholdet mellem kvalitetssikring og undervisning. For det første må de standarder, regler, normer, man følger i undervisning, forstås som erfaringsbaserede og dermed 'åbne'. Dvs. at deres rette anvendelse nødvendigvis afhænger af den konkrete situation og den enkelte undervisers erfaring (partikularisme-pointen). For det andet kan de eksplicitte standarder, regler, normer, som oftest opstilles i kvalitetssikring, principielt ikke fremstille den viden, som udfoldes $\mathrm{i}$ god undervisning (ukodificerbarheds-pointen). Slutteligt kan kvalitetssikringens fokus på eksplicitte standarder, regler, normer betyde, at man mister opmærksomheden over for det centrale element i god undervisning, nemlig erfaringen fra den konkrete undervisningssituation (praktisk fornuft-pointen).

Eksplicitismen kan altså undergrave undervisningens essentielle erfaringsgrundlag. Dette bør få os til at skelne mellem to forskellige typer af redskaber til at sikre kvalitet. På den ene side de redskaber, som søger at gøre undervisningens resultater målelige eller bare tilgængelige for den ikke-fagligt funderede og ikke-undervisningserfarne observatør (for eksempel evalueringer, akkrediteringer og $\mathrm{i}$ et vist omfang taxameterordninger). På den anden side redskaber, der tager afsæt i den konkrete, fagligt begrundede undervisningssituation (for eksempel kompetencemål, supervision og universitetspædagogisk efteruddannelse generelt). De redskaber, der findes i den forste gruppe, kan primært bruges til ekstern monitorering af undervisningen, men ikke til at kvalitetssikre den, fordi de overser eller ligefrem tilsidesætter dens erfaringsbundne karakter. Kvalitetsmonitorering og kvalitetsudvikling er to forskellige ting, og hvis man ønsker at arbejde med egentlig udvikling af undervisning, må man bruge redskaber fra den anden gruppe, som tager udgangspunkt i underviserens konkrete erfaring. Beskrivelsen af undervisnings erfaringsbaserede karakter viser os, at der er en konflikt mellem den eksterne og interne målsætning med kvalitetssikring. Det betyder, at man må skelne mellem de redskaber, der kan bruges til at monitorere kvalitet, og de, som kan udvikle den. Man kan ikke ukritisk gå ud fra, at begge dele kan gøres på én og samme tid.

\section{Litteratur}

Ace Denmark (2009). Vejledning om akkreditering og godkendelse af eksisterende universitetsuddannelser, 2. rev. udgave,

www.acedenmark.dk/fileadmin/user_upload/dokumenter/Akkreditering_dokumenter/Vejledning_om_akkreditering_og_ godkendelse_af_eksisterende_udddannelser_-_Januar_2009.pdf Aristoteles (1953). The Nicomachean Ethics, London: Penguin.

Carr, D. (2003). "Rival Conceptions of Practice in Education and Teaching", Journal of the Philosophy of Education 37:2, side 253-266.

Christensen, A.-M. S. (2009). »'Getting it Right' in Ethical Experience: John McDowell and Virtue Ethics». Forthcoming The Journal of Value Inquiry.

Christensen, A.-M. S. (2008). Moderne dydsetik, Århus: Aarhus Universitetsforlag.

Dahler-Larsen, P. (2008).Kvalitetens beskaffenhed, Odense: Syddansk Universitetsforlag.

Dunne, J. (1999). „Virtue, Phronesis and Learning« i Steutel og Carr: Virtue Ethics and Moral Education, London: Routledge. 
Dunne, J. (2003). "Arguing for teaching as a Practice: a Reply to Alasdair MacIntyre ", Journal of the Philosophy of Education 37:2, side 353-369.

Dunne, J. (2005). »An Intricate Fabric: Understanding the Rationality of Practice«, Pedagogy, Culture and Society 13:3, side 367-389.

Garfield, J. (2000), "Particularity and Principle: The Structure of Moral Knowledge" i Hooker and Little: Moral Particularism, Oxford: Clarendon Press.

Hursthouse, R. (1999). On Virtue Ethics, Oxford: Oxford University Press.

Lave, J. og Wanger, E. (1991), Situated Learning: Legitimate Peripheral Participation, New York: Cambridge University Press.

Lovibond, S. (2002). Ethical Formation, Cambridge Mass.: Harvard University Press.

MacIntyre, A. og Dunne, J. (2002). "Alasdair MacIntyre on Education: In Dialogue with Joseph Dunne", Journal of Philosophy of Education 36:1, side 1-19.

McDowell, J. (1979),»Virtue and Reason« i Mind, Value, and Reality, Cambridge Mass.: Harvard University Press 1998.

McDowell, J. (1996). »Two Sorts of Naturalism« i Mind, Value, and Reality, Cambridge Mass.: Harvard University Press 1998.

Ministeriet for Videnskab, teknologi og uddannelse.VTU (2009), "Uddannelsernes kvalitet«, http://vtu.dk/uddannelse/uddannelsernes-kvalitet.

O’Neill, O. (2002). A Question of Trust, Cambridge: Cambridge University Press.

Power, M. (1997). The Audit Society: Rituals of Verification, Oxford: Oxford University Press.

Sander, H. (2006). »Vejen gennem studiet skal lettes«, DM stud. bladet nr.2, www.dm.dk/OmDM/SektorerOgSektioner/Sektorer/ Studerende/dmstudBladet/Arkiv/nr2april2006/Vejengennemstudietskallettes.aspx.
Saugsted, T. (2005). "Aristotle's Contribution to Scholastic and Non-Scholastic Learning Theories", Pedagogy, Culture and Society 13:3, side 347-368.

Smeyers, P. (1992). »The Necessity for Particularity in Education and Child-Rearing", The Journal of Philosophy of Education 26:1, 63-73.

Wittgenstein, L. (1953). Philosophische Untersuchungen/Philosophical Investigations, Oxford: Blackwell 2001.

\section{Noter}

1 Jeg vil gerne takke to anonyme reviewers for Dansk Universitetspaedagogisk Tidsskrift for præcise kommentarer til en tidligere version af denne artikel.

2 PåVidenskabsministeriets hjemmeside præsenteres videreuddannelse, evalueringer og akkreditering som de tre relevante redskaber i kvalitetssikring af universitetsuddannelse (VTU 2009). På linje med dette fremhæverVidenskabsminister Helge Sander $i$ en tale fra 2006 to redskaber til sikring af undervisningens kvalitet, nemlig uddannelse og offentliggørelsen af systematiske studenterevalueringer (Sander 2006).

3 Peter Dahler-Larsen argumenterer ligefrem for, at dette er et uundgåeligt resultat af kvalitetsmåling (Dahler-Larsen 2008, 92-94).

4 Der er selvfølgelig også forudsætninger, som den studerende bør have, men det er ikke emnet her. 